\title{
SISTEM PENGUNCI APLIKASI MENGGUNAKAN TIMER BERBASIS ANDROID
}

\author{
Wahyu Purnama Sari ${ }^{1}$, Yiyi Supendi ${ }^{2}$, Deden Wahyudi Julianto ${ }^{3}$ \\ Program Studi Teknik Informatika ${ }^{1,2,3}$ \\ Universitas Langlangbuana ${ }^{1,2,3}$ \\ wahyu.alyapurnama@gmail.com ${ }^{1}$,yiyi.supendi@gmail.com², dedenwahyudi101@gmail.com ${ }^{3}$
}

\begin{abstract}
Abstrak
Perkembangan jaman dewasa ini telah menempatkan teknologi informasi sebagai layanan yang tidak terpisahkan dari kehidupan sehari-hari manusia. Perangkat komunikasi smartphone hampir dimiliki oleh seluruh penduduk dunia. Dunia dalam genggaman, itulah realita hidup manusia saat ini. Segala kegiatan dalam berbagai sektor mulai dialihkan dengan pemanfaatan aplikasi untuk mempermudah kerja manusia. Aplikasi-aplikasi berkembang setiap harinya, mulai aplikasi hiburan, pendidikan, perbankan, niaga/ecommerce, media sosial dan yang lainnya. Semua aplikasi ini dapat diunduh melalui layanan playstore pada platform Android. Pada penggunaan smartphone, telah banyak dikembangkan aplikasi pengunci untuk mengamankan data dari akses pihak-pihak yang tidak bertanggungjawab. Aplikasi pengunci ini biasanya digunakan pada saat seseorang memulai untuk membuka smartphone yang dimiliki. Sehingga ketika seseorang telah berhasil masuk ke system, maka akan mudah untuk membuka aplikasi-aplikasi lainnya dalam smartphone tersebut. Sistem pengunci aplikasi dengan menggunakan timer akan membantu seseorang untuk melindungi data-data dalam aplikasi yang terinstal dalam platform android. Aplikasi tertentu dapat dikunci menggunakan durasi waktu yang telah ditentukan. Selama durasi penguncian aplikasi berlangsung, maka interface aplikasi tersebut akan disembunyikan, sehingga tidak dapat terlihat oleh user yang menggunakannya. Aspek yang dilindungi mencakup Availability, Integrity dan Confidentiality.

Kata kunci: Smartphone, Android, Sistem Pengunci Aplikasi, Timer
\end{abstract}

\begin{abstract}
The development of today's era has placed information technology as an inseparable service from human daily life. Smartphone communication devices are almost owned by the entire world population. The world is in hand, that is the reality of human life today. All activities in various sectors began to be shifted to the use of applications to facilitate human work. Applications are developing every day, ranging from entertainment applications, education, banking, commercele-commerce, social media and others. All of these applications can be downloaded through the playstore service on the Android platform. In the use of smartphones, many locking applications have been developed to secure data from access by irresponsible parties. This lock application is usually used when someone starts to open their smartphone. So that when someone has successfully entered the system, it will be easy to open other applications on the smartphone. The application lock system using a timer will help someone to protect the data in applications installed on the android platform. Certain apps can be locked using a predefined time duration. For the duration of the application lock, the application interface will be hidden, so that it cannot be seen by the user who uses it. Aspects that are protected include Availability, Integrity and Confidentiality.
\end{abstract}

Keywords: Smartphone, Android, App Lock System, Timer

\section{PENDAHULUAN}

Penggunaan smartphone oleh sebagian besar masyarakat masih belum memperhatikan aspek-aspek keamanan. Keamanan data-data yang tersimpan dalam smartphone harus dilindungi dari akses pihak-pihak yang tidak bertanggungjawab. Kelalaian dalam mengamankan data-data privasi dapat berkakibat fatal terhadap hilangnya data-data penting, modifikasi dan pemalsuan. Sesekali terkadang smartphone tergeletak di sembarang tempat di rumah atau di kendaraan pribadi. Tentunya ini akan menjadi sasaran anak-anak untuk menggunakannya tanpa pengawasan. Atau mungkin bisa saja smartphone orangtua yang digunakan anak-anak untuk belajar dalam jaringan (Daring). Pengamanan aplikasi berupa Personal Identification Number (PIN), Pola Password, kata sandi dan lain-lain merupakan langkah awal untuk melindungi system dari akses pihak lain. Ketika seseorang berhasil mengetahui PIN/Pola/Sandi Smartphone, maka akan mudah untuk membuka semua aplikasi yang terinstal dalam smartphone tersebut, karena semua aplikasi terpampang dalam platfoem yang digunakan. Sistem pengunci aplikasi dikembangkan dengan tujuan untuk menyembunyikan aplikasi-aplikasi tertentu dalam smartphone dari pandangan user. Dengan durasi yang telah diatur, dan aplikasi yang dipilih, maka aplikasi ini akan dikunci oleh system. Selama aplikasi disembunyikan, tampilan/interface akan dialihkan ke notifikasi berupa gambar tanpa menggangu layanan aplikasi lainnya. Hal ini tentunya akan membantu bagi mereka yang masih harus berbagi penggunaan Smartphone secara bergantian dengan anak-anak. Aplikasi tertentu dapat disembunyikan selama smartphone tersebut digunakan oleh pihak lain (anak-anak). 


\section{TINJAUAN PUSTAKA}

\section{Smartphone}

Smartphone adalah telepon genggam yang memiliki fitur kegunaan yang berfungsi yang menyerupai komputer. Sampai saat ini belum ada standar pabrik yang menentukan arti dari smartphone. Bagi beberapa orang smartphone merupakan telepon genggam yang bekerja menggunakan semua perangkat lunak sistem operasi yang memiliki hubungan standar dan mendasar bagi pengembang aplikasi[1].

Sistem Android adalah sebuah system operasi untuk perangkat bergerak berbasis linux yang mencakup sistem operasi, middleware, dan aplikasi. Android menyediakan platform yang terbuka untuk agar para pengembang untuk menciptakan aplikasi mereka sendiri. Pada awalnya, Google Inc. membeli Android Inc. yang merupakan pendatang baru dalam pengembangan piranti lunak untuk ponsel atau smartphone[2].

Android mempunyai berbagai keunggulan sebagai software yang mengunakan basis kode komputer yang bisa dibagikan secara terbuka (open source) sehingga pengguna dapat dengan mudahnya membuat aplikasi baru di dalamnya. Android mempunyai aplikasi native Google yang terintegrasi seperti pushmail Gmail, Google Maps, dan Google Calendar[3].

Android Studio merupakan lingkungan terpadu atau Integrated Development Environment (IDE) yang resmi untuk pengembangan aplikasi Android, yang didasarkan kepada IntelliJ IDEA. Selain sebagai editor kode dan fitur developer IntelliJ yang handal, Android Studio juga menawarkan beberapa fitur-fitur yang dapat meningkatkan produktivitas Anda saat membuat suatu aplikasi Android, keuntungan bisa dilihat seperti dibawah ini: [4]

a. Emulator yang cepat dan memiliki berbagai fitur

b. Lingkungan terpadu tempat untuk bisa mengembangkan aplikasi untuk semua perangkat Android

c. Terapkan Perubahan untuk melakukan push pada perubahan kode dan resource ke aplikasi yang sedang berjalan tanpa memulai ulang aplikasi atau bisa dikenal auto save

d. Template kode dan integrasi GitHub untuk membantu Anda membuat fitur-fitur yang mempunyai banyak fungsi untuk aplikasi umum dan mengimpor beberapa kode untuk sampel

e. Framework dan alat pengujian yang lengkap

f. Alat lint untuk merekam performa, kegunaan, kompatibilitas versi, dan masalah lainnya

g. Dukungan dari $\mathrm{C}++$ dan NDK

h. Dukungan bawaan untuk produk Google Cloud Platform, yang memudahkan integrasi Google Cloud Messaging dan App Engine

i. Sistem build berbasis Gradle yang fleksibel Android Studio merupakan Integrated Development Environment (IDE) yang jika diartikan menjadi Lingkungan Pengembangan Terpadu official yang dikeluarkan oleh Google untuk Android. IDE yang pertama kali rilis tahun 2014 ini mempunyai banyak sekali fungsi yang perlukan oleh para developer ketika pengembangan aplikasi Android seperti melakukan build, test, debug, dan lain sebagainya.

\section{Rapid Application Development (RAD)}

Terdapat tiga fase dalam Rapid Aplication Development (RAD) yang melibatkan penganalisis dan pengguna dalam tahap penilaian, perancangan, dan penerapan. Adapun ketiga fase tersebut adalah requirements planning (perencanaan syarat-syarat), RAD design workshop (workshop desain RAD), dan implementation (implementasi). Gambar 1 merupakan siklus model RAD[5].

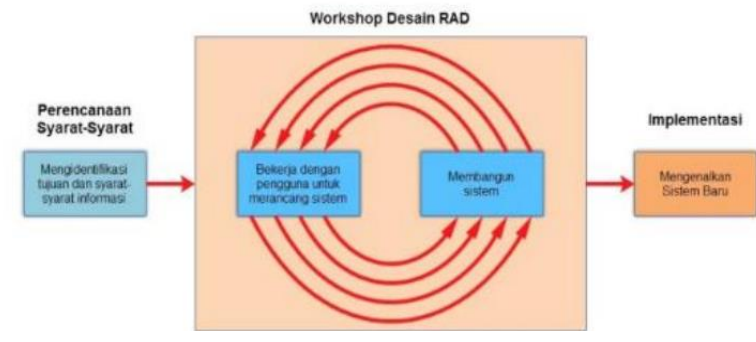

Gambar 1. Siklus model RAD [5]

Adapun tahapan model RAD dapat dijelaskan sebagai berikut:

a. Requirements Planning (Perencanaan Syarat-Syarat) Dalam fase ini, pengguna dan penganalisis bertemu untuk mengidentifikasikan tujuan-tujuan aplikasi atau sistem serta untuk megidentifikasikan syarat-syarat informasi yang ditimbulkan dari tujuantujuan tersebut. Orientasi dalam fase ini adalah menyelesaikan masalah-masalah perusahaan. Meskipun teknologi informasi dan sistem bisa mengarahkan sebagian dari sistem yang diajukan, fokusnya akan selalu tetap pada upaya pencapaian tujuan-tujuan perusahaan.

b. Workshop Desain RAD Fase ini adalah fase untuk merancang dan memperbaiki yang bisa digambarkan sebagai workshop. Penganalisis dan dan pemrogram dapat bekerja membangun dan menunjukkan representasi visual desain dan pola kerja kepada pengguna. Workshop desain ini dapat dilakukan selama beberapa hari tergantung dari ukuran aplikasi yang akan dikembangkan. Selama workshop desain RAD, pengguna merespon prototipe yang ada dan penganalisis memperbaiki modul-modul yang dirancang berdasarkan respon pengguna. 
c. Implementation (Implementasi) Pada fase implementasi ini, penganalisis bekerja dengan para pengguna secara intens selama workshop dan merancang aspek-aspek bisnis dan nonteknis perusahaan. Segera setelah aspekaspek ini disetujui dan system-sistem dibangun dan disaring, sistem-sistem baru atau bagian dari sistem diujicoba dan kemudian diperkenalkan kepada organisasi.

3. Unified Modelling Language (UML)

Unified Modelling Language (UML) adalah bahasa yang digunakan untuk menentukan, memvisualisasi, membangun dan mendokumentasikan artifacts (bagian dari informasi yang digunakan untuk dihasilkan pada proses pembuatan perangkat lunak, biasanya artifact tersebut dapat berupa model, deskripsi atau perangkat lunak) dari sistem perangkat lunak, seperti pada pemodelan bisnis dan system non-perangkat lunak lainnya. Selain itu UML merupakan Bahasa pemodelan yang menggunakan konsep orientasi object.

UML merupakan bahasa visual saat pemodelan dan komunikasi mengenai sebuah sistem dengan menggunakan diagram dan teks-teks pendukung". Beberapa permodelan yang termasuk kepada pemodelan UML seperti use case diagram, class diagram, activity diagram, dan sequence diagram.

\section{ANALISIS DAN PERANCANGAN}

Analisis merupakan aktivitas yang dilakukan untuk mendefinisikan proses yang terjadi pada sistem saat ini untuk kemudian diusulkan sistem yang akan di bangun. Proses bisnis digunakan untuk mempermudah pendeskripsian alur sistem yang terjadi. Analisis proses bisnis ini bertujuan untuk menguraikan proses secara sistematis system pengunci yanga akan dikembangkan

1. Analisis Sistem Saat Ini.

Analisis ini menggambarkan tentang prosedur mengunci aplikasi. Gambaran proses bisnis saat ini dapat dilihat pada gambar 2 .

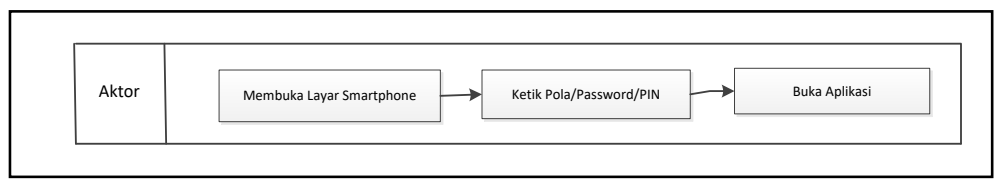

Gambar 2. Proses Bisnis Saat Ini

Proses bisnis yang terjadi saat ini hanya merupakan prosedur penguncian aplikasi menggunakan PIN/Pola/Password atau kata sandi pada saat akan membuka smartphone

2. Analisis Sistem Yang Diusulkan

Analisis sistem yang diusulkan menggambarkan tentang prosedur sistem pengunci aplikasi yang diusulkan. Adapun gambaran proses bisnis dapat dilihat pada gambar 3

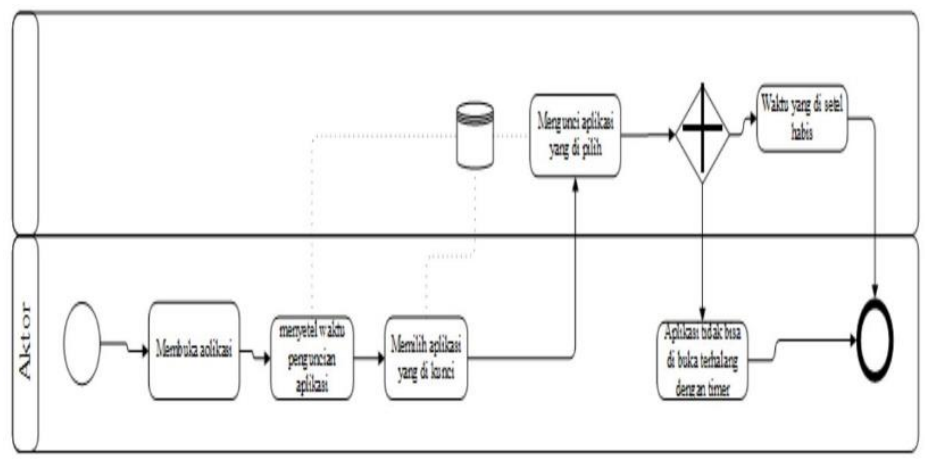

Gambar 3. Proses Bisnis yang Diusulkan

Pada gambar 3 dijelaskan ketika user membuka aplikasi, user akan diarahkan untuk mengatur waktu punguncian aplikasi kemudian memilihnya dan mulai melakukan penguncian. Selama rentang waktu penguncian, interface icon aplikasi yang dipilih akan disembunyikan sampai timer yang telah di atur selesai.

3. Use Case Diagram

Use Case digunakan untuk mengetahui prosedur system penguncian aplikasi. 


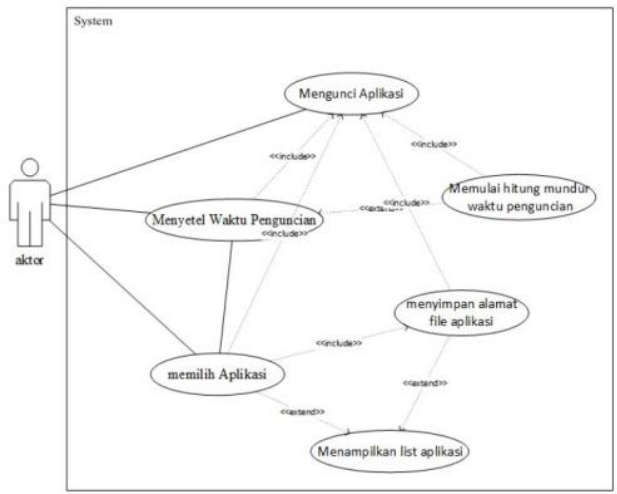

Gambar 4. Use Case Diagram

Adapun untuk scenario Use Case Diagram dijelaskan pada tabel 1 samapi dengan tabel 3 berikut: Skenario Use Case Diagram Aplikasi dijelaskan pada tabel 1.

TABEL I

SKENARIO USE CASE MENYETEL WAKTU PENGUNCIAN

\begin{tabular}{|c|c|}
\hline \multicolumn{2}{|l|}{ Use case Login } \\
\hline Aktor & Pengguna aplikasi \\
\hline Tujuan & Menyetel waktu penguncian \\
\hline Kondisi Awal & User membuka aplikasi \\
\hline \multicolumn{2}{|l|}{ Skenario } \\
\hline Aksi Aktor & Reaksi Sistem \\
\hline \multicolumn{2}{|l|}{$\begin{array}{l}\text { Aktor membuka aplikasi } \\
\text { applock }\end{array}$} \\
\hline & 2. Memeriksa waktu terakhir penguncian \\
\hline & 3. Menampilkan halaman timer. \\
\hline \multicolumn{2}{|l|}{$\begin{array}{l}\text { 4. Memasukan lama waktu } \\
\text { penguncian aplikasi }\end{array}$} \\
\hline & $\begin{array}{l}\text { 5. Sistem menyimpan lama penguncian aplikasi } \\
\text { dengan satuan menit }\end{array}$ \\
\hline \multirow[t]{4}{*}{$\begin{array}{ll}\text { 6. } & \text { Aktor mejalankan waktu yang } \\
\text { telah di tentukan dengan } \\
\text { menekan tombol start }\end{array}$} & \\
\hline & 7. Sistem menjalankan hitung mundur \\
\hline & $\begin{array}{l}\text { 8. Sistem membuka halamanpengingat agar aplikasi } \\
\text { tidak dibuka hingga waktu hitung mundur selesai }\end{array}$ \\
\hline & $\begin{array}{l}\text { 9. Sistem kembalike aplikasi pengunci ketika waktu } \\
\text { habis }\end{array}$ \\
\hline
\end{tabular}

TABEL II

SKENARIO USE CASE MEMILIH APLIKASI

\begin{tabular}{|c|c|c|}
\hline \multicolumn{3}{|l|}{ Use case Login } \\
\hline Aktor & \multicolumn{2}{|c|}{ Pengguna aplikasi } \\
\hline Tujuan & \multicolumn{2}{|c|}{ Menyetel waktu penguncian } \\
\hline Kondisi Awal & \multicolumn{2}{|c|}{ User memilih aplikasi yang akan di kunci } \\
\hline \multicolumn{3}{|l|}{ Skenario } \\
\hline \multicolumn{2}{|l|}{ Aksi Aktor } & Reaksi Sistem \\
\hline \multirow[t]{4}{*}{$\begin{array}{ll}\text { 1. } & \text { Aktor } \\
& \text { aplikasi applock }\end{array}$} & Membuka & \\
\hline & & $\begin{array}{l}\text { 2. Memeriksa aplikasi yang di install pada } \\
\text { smartphone. }\end{array}$ \\
\hline & & 3. Memeriksa aplikasi yang sudah dikunci \\
\hline & & 4. menampilkan halaman aplikasi yang di install \\
\hline
\end{tabular}


NARATIF(Jurnal Ilmiah Nasional Riset Aplikasi dan Teknik Informatika)

Vol. 03 No. 02 Desember 2021

P-ISSN: 2656-7377 || E-ISSN: 2714-8467

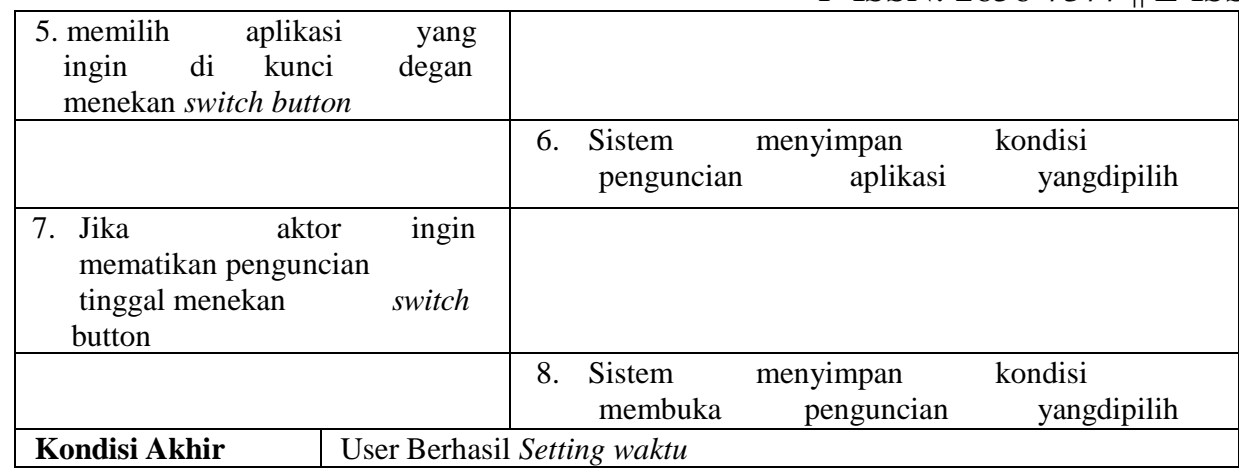

TABEL III

SKENARIO USE CASE MENGUNCI APLIKASI

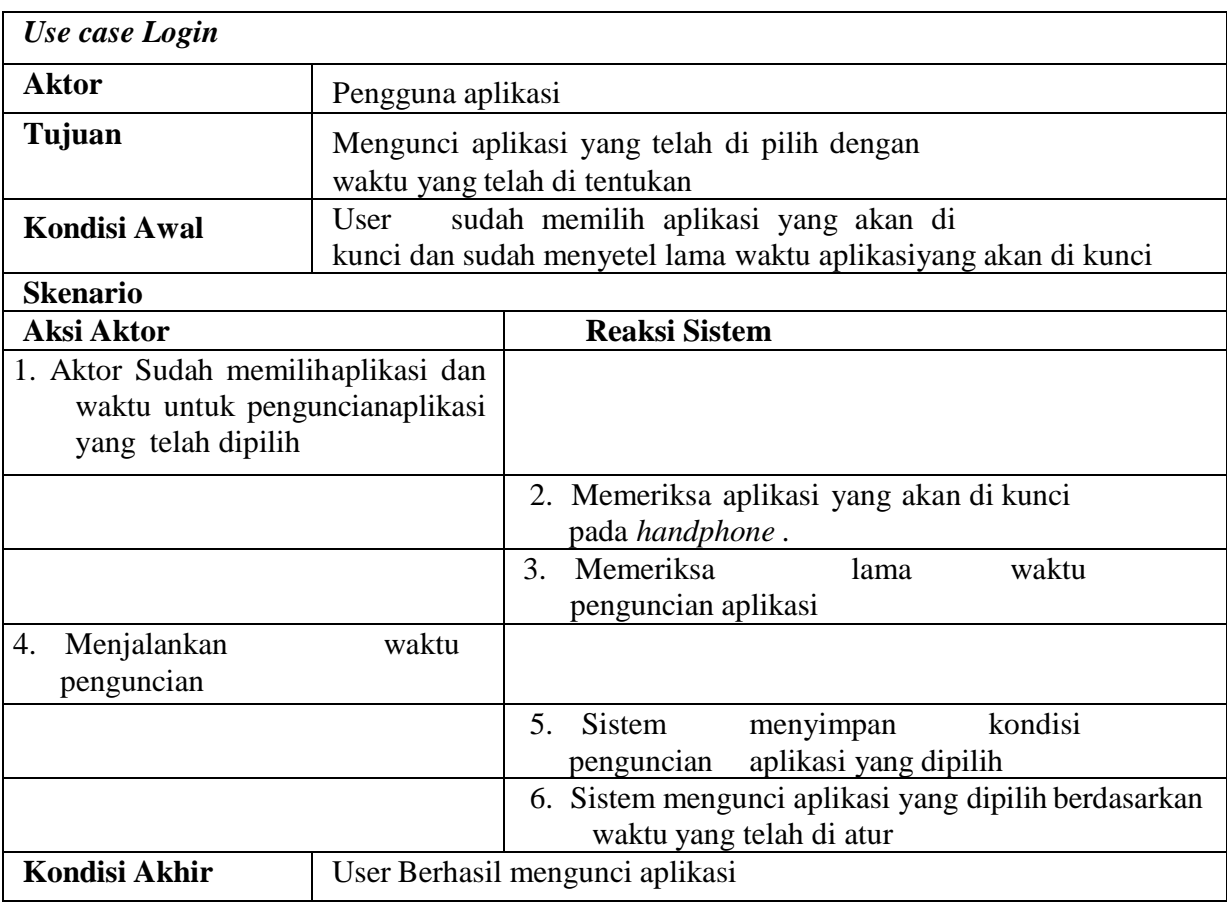

4. Perancangan Interface

Perancangan interface merupakan gambaran interface tampilan dari system pengunci aplikasi yang akan di buat.

a. Interface Daftar Aplikasi

Gambar 5 merupakan interface daftar aplikasi yang di install pada smartphone.

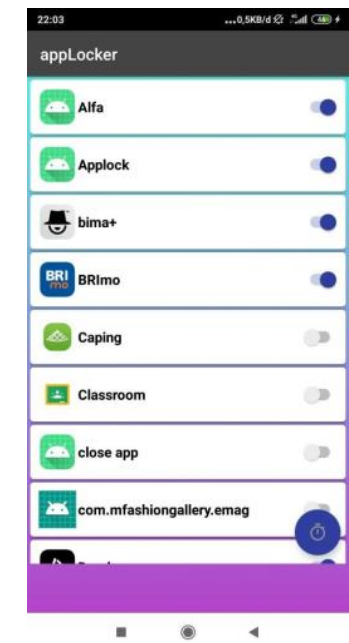

Gambar 5. Interface Daftar Aplikasi

b. Interface Setting Waktu

Gambar 6 merupakan Interface pengaturan waktu yang akan dijalankan pada system pengunci. Ketika waktu 
(menit) pengunci di atur maka menit akan otomatis di konversi menjadi satuan jam.

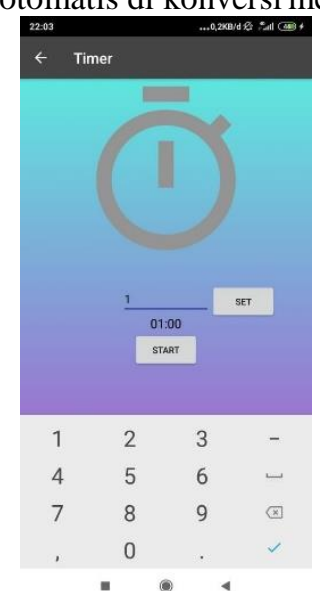

Gambar 6. Interface Setting Waktu

c. Interface Pengingat Aplikasi yang Terkunci

Gambar 7 merupakan Interface pengingat Aplikasi yang Terkunci.

Gambar 7. Interface Pengingat Aplikasi yang Terkunci

5. Implementasi

Implementasi merupakan aktivitas untuk menerjemahkan desain ke dalam Bahasa pemrograman. Berikut ditampilkan coding dalam system pengunci aplikasi pada smartphone. Gambar 8 sampai gambar 11 merupakan gambar sintak coding system pengunci aplikasi

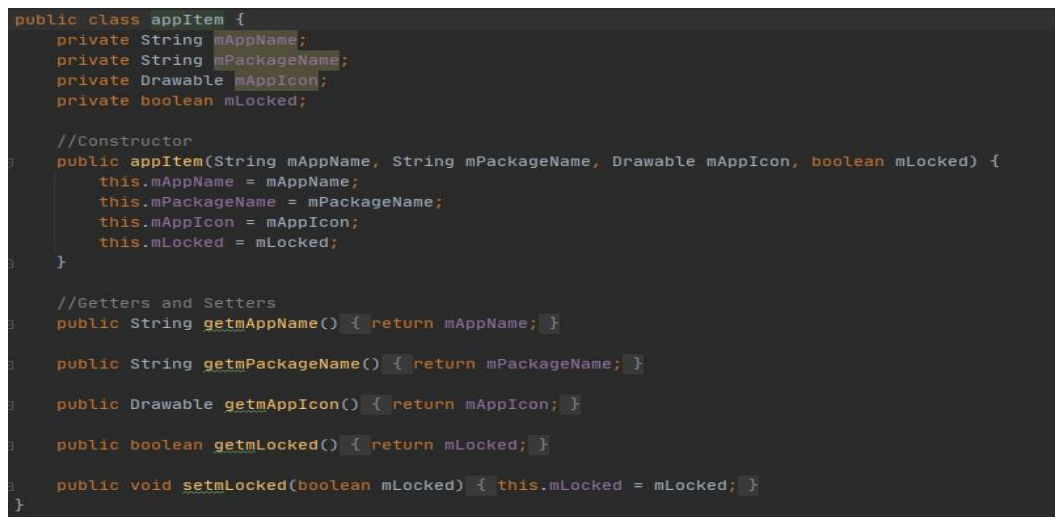

Gambar 8. Coding inisialisasi daftar aplikasi 
NARATIF(Jurnal Ilmiah Nasional Riset Aplikasi dan Teknik Informatika)

Vol. 03 No. 02 Desember 2021

P-ISSN: 2656-7377 || E-ISSN: 2714-8467

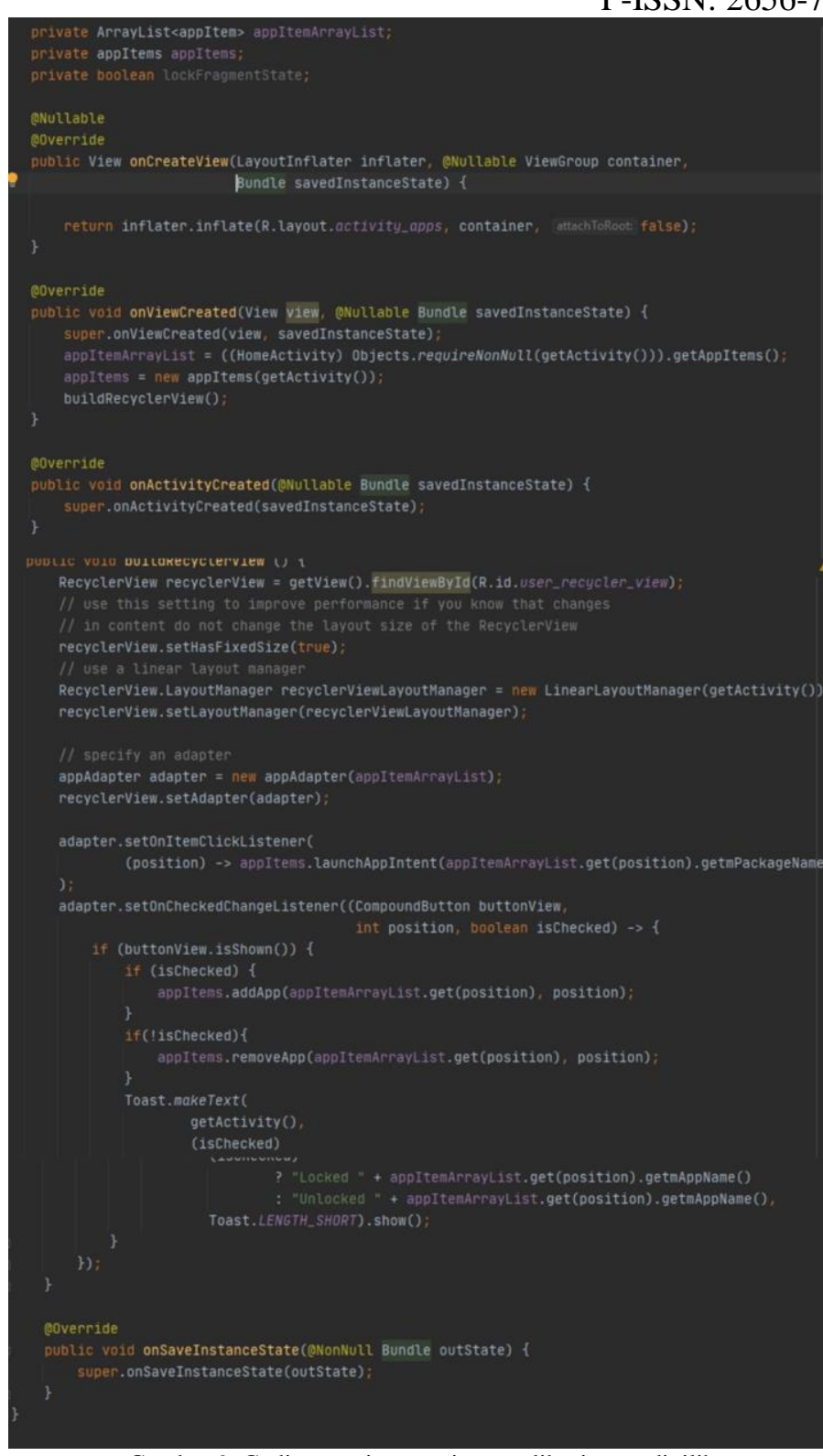

Gambar 9. Coding service pengingat aplikasi yang dipilih

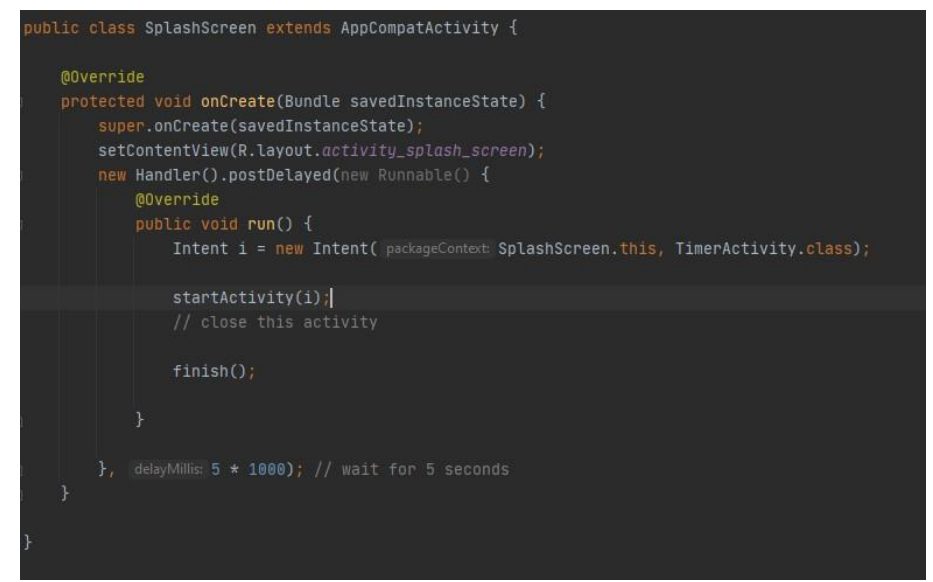

Gambar 10. Coding kondisi pengalihan halaman 
NARATIF(Jurnal Ilmiah Nasional Riset Aplikasi dan Teknik Informatika)

Vol. 03 No. 02 Desember 2021

P-ISSN: 2656-7377 || E-ISSN: 2714-8467

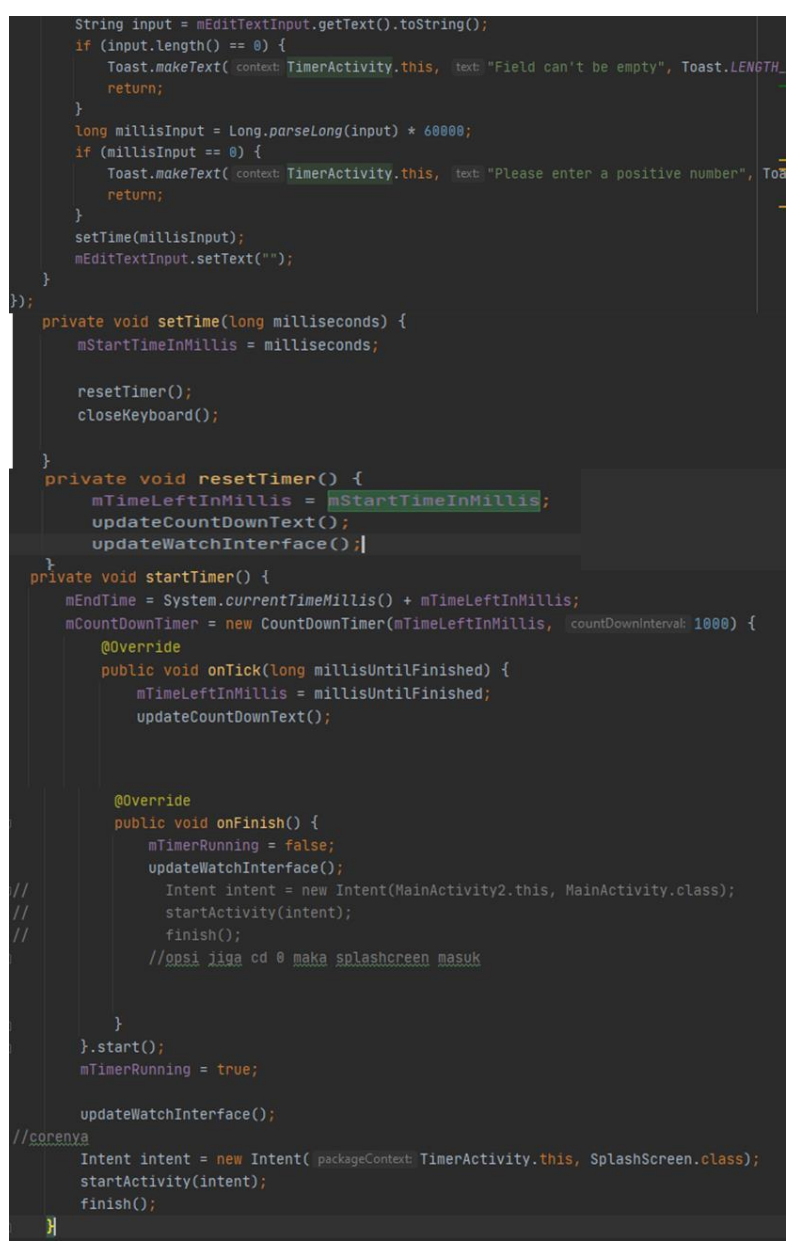

Gambar 11. Coding Timer

\section{KESIMPULAN}

Berdasarkan hasil analisis dan pembahasan yang telah dilakukan, dapat disampaikan hal-hal sebagai berikut:

a. Sistem pengunci aplikasi akan menampilkan daftar aplikasi yang telah di install kemudian memilih aplikasi yang akan di kunci selanjutnya akan diarahkan ke halaman isi waktu (timer) yang akan di atur dan tekan tombol start dan aplikasi yang dipilih. Selama durasi waktu (timer) yang telah di tetapkan, maka aplikasi yang dipilih untuk di kunci tidak akan dapat di buka (disembunyikan dari pandangan user) hingga waktu selesai.

b. Hitung waktu mundur yang telah di set berjalan sesuai waktu yang ditentukan menggunakan metode timer dan countdown di android studio.

\section{REFERENSI}

[1] Daeng, I. T. M., Mewengkang, N. N., \& Kalesaran, E. R. (2017). Penggunaan smartphone dalam menunjang aktivitas perkuliahan oleh mahasiswa fispol unsrat manado. Acta Diurna Komunikasi, 6(1).

[2] Bahagia, B., Satria, D., \& Ahmadian, H. (2017). Perancangan sistem informasi manajemen data korban bencana berbasis mobile Android. JEMSI (Jurnal Ekonomi, Manajemen, dan Akuntansi), 3(2), 22-30

[3] https://salamadian.com

[4] https://developer.android.com.

[5] Kendall, K. E. dan Kendall, J. E. Analisis dan Perancangan Sistem. PT Indeks, Jakarta, 2010

[6] https://www.dicoding.com

[7] Syarif, M., \& Nugraha, W. (2020). Pemodelan Diagram Uml Sistem Pembayaran Tunai Pada Transaksi E-Commerce. JTIK (Jurnal Teknik Informatika Kaputama), 4(1), 64-70. 